\title{
Autochthonous transmission of Chagas disease in Rio de Janeiro State, Brazil: a clinical and eco-epidemiological study
}

Luiz Henrique Conde Sangenis ${ }^{1 *}$, Roberto Magalhães Saraiva', Ingebourg Georg ${ }^{2}$, Liane de Castro ${ }^{3}$, Valdirene dos Santos Lima ${ }^{4}$, André Luiz R Roque ${ }^{4}$, Samanta Cristina das Chagas Xavier ${ }^{4}$, Laura Cristina Santos ${ }^{5}$, Fabiano A Fernandes ${ }^{6}$, Otília Sarquis ${ }^{6}$, Marli Maria Lima ${ }^{6}$, Filipe Aníbal Carvalho-Costa ${ }^{7}$ and Márcio Neves Bóia ${ }^{8}$

\begin{abstract}
Background: After the control of the main modes of Chagas disease (CD) transmission in most endemic countries, it is important to identify the participation of native sylvatic vectors in $C D$ transmission. Although $C D$ is not considered endemic in Rio de Janeiro State (RJ), Brazil, we identified patients with CD born in RJ and investigated the possible autochthonous transmission in the state.

Methods: Patients born in RJ and followed in our institution between 1986 and 2011 were retrospectively analyzed. The cases identified as autochthonous transmission were submitted to epidemiological, clinical, serological, parasitological and molecular studies. Sectional field study with serological survey, research of sylvatic reservoirs and vectors was conducted in rural areas where patients were born.

Results: Among 1963 patients, 69 (3.5\%) were born in RJ. From these, 15 (21.7\%) were considered to have acquired the infection by autochthonous transmission. Cardiac form was the commonest form of presentation (60\%). In rural areas in RJ northern region, sylvatic cycles of Trypanosoma cruzi and domestic invasion by Triatoma vitticeps were identified, and CD prevalence among inhabitants was $0.74 \%$.Tcl genotype was identified in sylvatic reservoirs and vectors. The genotype (mixed infection $\mathrm{Tcl} / \mathrm{TcVI}$ ) could be identified in one of the autochthonous cases.

Conclusions: The autochthonous vectorial transmission of CD occurs in RJ, probably due to wild cycles of T. cruzi and sylvatic vectors, such as T. vitticeps. Therefore, the health authorities should evaluate if RJ should be included in the original endemic area of CD and CD should be included in the diagnostic work out of cardiomyopathy of patients born in RJ. Moreover, control and educational measures should be put into place in the risk areas.
\end{abstract}

Keywords: Chagas disease, Trypanosoma cruzi, Epidemiology, Clinical, Transmission, Genotypes, Triatoma vitticeps, Rio de Janeiro

\section{Background}

Although the main modes of Chagas disease (CD) transmission (domestic vectorial transmission by Triatoma infestans and Rhodnius prolixus, and blood transfusion) are controlled in most endemic countries, 28 million people are still at risk to acquire CD in Latin America [1]. Vectorial transmission by native vectors maintains the risk of $\mathrm{CD}$

\footnotetext{
* Correspondence: luiz.sangenis@ini.fiocruz.br

'Laboratório de Pesquisa Clínica em Doença de Chagas, Instituto Nacional de Infectologia Evandro Chagas, Fundação Oswaldo Cruz, Rio de Janeiro, RJ Brazil

Full list of author information is available at the end of the article
}

transmission in Brazil and other areas of the Americas [2-7]. In Brazil, the original endemic area was based on the domestic vector distribution, primarily in the regions where $T$. infestans was present as well as that of native triatomine bugs adapted to the domestic environment, such as Panstrongylus megistus and Triatoma brasiliensis $[8,9]$. Therefore, CD was never considered endemic in Rio de Janeiro State (RJ), given the apparent domestic distribution of triatomine bugs and vectorial transmission [8-10].

Most patients with CD diagnosed in RJ over past decades were imported from endemic areas as metropolitan regions in southeastern Brazil were the main destinations 
of migration flows from rural regions during the $20^{\text {th }}$ century [11-14]. However, cases possibly acquired in RJ were identified and mostly attributed to blood transfusion, travel history of patients born in RJ to other endemic states, and rarely to congenital transmission [12]. Nevertheless, the transmission route in patients with CD born in RJ remained unclear in some cases that could be autochthonous cases $[11,12,15]$.

The possible occurrence of autochthonous cases of CD in RJ is studied since 1943 when sylvatic reservoirs and vector infected by $T$. cruzi were identified in Rio de Janeiro city [16]. Some studies documented serologically positive cases of the disease but did not investigate other possible routes of transmission $[11,13,15,17]$. Despite the occurrence of domestic invasion by Triatoma vitticeps at various locations in the state of RJ and its recognized role as CD transmitter in Espírito Santo State (ES), the long interval between feeding and defecation has always put their role in CD transmission into question [18-25]. Therefore, CD autochthonous cases in RJ were not fully recognized. However, over the past few years, focus of $\mathrm{CD}$ had occurred in rural areas of RJ where specimens of $T$. vitticeps were collected inside houses [22,23]. Human cases of CD were identified in these locations, calling attention to the possible vectorial transmission of the disease in this state.

The present study describes the clinical and epidemiological characteristics of 15 patients with $C D$ acquired in RJ and through a cross-sectional field study in rural areas of the state, gives insight into the mechanism of vectorial transmission in this state.

\section{Methods}

Study design and collection of epidemiological, clinical, and laboratory data

We retrospectively reviewed all patients with $\mathrm{CD}$ admitted and followed at the Instituto Nacional de Infectologia Evandro Chagas (INI), Oswaldo Cruz Foundation (FIOCRUZ), between 1986 and 2011. The mechanism of transmission was studied in all patients who were born in RJ and was based on the following criteria: (i) Congenital transmission: those who had mothers native to endemic regions of $\mathrm{CD}$ or who were serologically positive for $\mathrm{CD}$ without further epidemiological evidence for the risk of acquiring the disease; (ii) Transmission through blood transfusion: all patients with a history of transfusion of hemoderivatives or organ transplantations before 1992 were placed in this group, even if they showed other risk factors, such as having a mother from an endemic region or who lived in a rural area; (iii) Transmission outside RJ: those who, despite being born in RJ, had traveled or lived in known endemic areas in other states; (iv) Autochthonous transmission: all risk factors for acquiring CD were excluded (mothers from known endemic regions of $\mathrm{CD}$, transfusion history of hemoderivatives or organ transplantation, living and traveling to endemic regions of CD outside RJ). Only the patients from the autochthonous group were included in this study.

The clinical classification followed the Brazilian Consensus on Chagas Disease: indeterminate form, cardiac form (stage A, B1, B2, C, and D), digestive form (megaesophagus grade I, II, III, and IV, as well as megacolon), and mixed form (cardiodigestive) [10].

The following variables were analyzed in the patients with signs of autochthonous transmission: age; sex; serological, parasitological, molecular, radiological, electrocardiographic (ECG), and echocardiographic findings; disease progression; death; treatment; clinical form; possible infection site; residence; eating habits; and knowledge of vectors. Epidemiological data were obtained from medical records and patient interviews and included exposure to vectors; blood transfusions; organ transplants; maternal history of CD; residence in rural areas; travel history from RJ to endemic regions; and consumption of risk food for the transmission of T. cruzi, such as meat of hunted wild mammals and beverages produced by artisans (e.g., juice from sugarcane and açaí palm (Euterpe edulis) native to the Brazilian Atlantic Forest). Death certificates of patients' mothers were also investigated, and the maternal serology for CD was tested whenever possible.

A field study was carried out in rural areas of north of RJ where the most recent cases of CD identified in this study occurred with evidence of vectorial transmission. Farms were visited, and blood samples were collected from residents for serological testing for CD. Small, wild, synanthropic mammals were captured, and the prevalence of $T$. cruzi infection was studied by parasitological and serological methods. Triatomine bugs found in houses were collected and their feces were searched for T. cruzi infection by direct microscopic examination and polymerase chain reaction (PCR).

\section{Case-series study \\ Serology}

Two serological techniques were used in the diagnosis of CD (indirect immunofluorescence [IIF; WAMA Diagnóstica, São Paulo, Brazil] and enzyme-linked immunosorbent assay [ELISA; Biozima Chagas kit, Buenos Aires, Argentina]) to detect anti-T. cruzi antibodies in the serum of the same sample obtained via peripheral venipuncture [10].

\section{Chest radiograph with esophageal contrast, electrocardiography, echocardiography, and digestive endoscopy}

All patients underwent posterior-anterior and laterolateral chest radiographs with contrast esophagogram and 12-lead ECG. All patients with Chagas cardiomyopathy underwent 2-dimensional echocardiography. The ejection 
fraction was calculated using the Teicholz index [26]. Patients with constipation for more than 7 days, dysphagia, or positive radiological findings of megaesophagus underwent digestive endoscopy.

\section{Indirect xenodiagnoses}

Peripheral blood samples $(8 \mathrm{~mL})$ were collected via venipuncture into vials containing heparin from patients with autochthonous evidence of vectorial transmission and were sent to the Laboratory of Parasitic Diseases, Instituto Oswaldo Cruz (IOC)/FIOCRUZ. Each sample was placed in a glass vial covered with latex film and stored at $37^{\circ} \mathrm{C}$. Forty third-stage and fourth-stage nymphs of $T$. infestans and $T$. vitticeps were placed in another glass container covered with fenestrated tissue and fed blood. After 45 days, each nymph was analyzed individually. The intestines were dissected, macerated, diluted in $0.9 \%$ saline and analyzed with a light microscope (400x) for T. cruzi.

\section{Hemoculture for T. cruzi}

A 5-mL peripheral blood sample was collected from each autochthonous patient into a vial containing ethylenediaminetetraacetic acid (EDTA) and immediately sent to the Laboratory of Tripanosomatid Biology at IOC/ FIOCRUZ. The sample was grown on liver infusion tryptose medium (LIT) for hemoculture and monitoring, as described by Lisboa et al. [27].

\section{Polymerase chain reaction}

Two 5-mL samples of peripheral blood were collected from each autochthonous patient into vials containing EDTA. One of them was sent to the Pharmacokinetic Laboratory at INI/FIOCRUZ for amplification of kinetoplast DNA (kDNA) by performing PCR, using total blood and commercial kits (QIAGEN ${ }^{\circ}$ [DNA Blood Mini Kit]), as described previously $[28,29]$. The other sample was sent to the Laboratory of Tripanosomatid Biology at IOC/FIOCRUZ for mini-exon multiplex PCR and restriction fragment length polymorphism (RFLP) analysis of the gene histone $\mathrm{H} 3$ and gp72 to identify the T. cruzi genotypes (TcI-TcVI) in serum, as described above, and according to the current $T$. cruzi nomenclature [30-33].

\section{Field study \\ Study areas}

Two rural sites north of RJ were studied. Area A included the Guarani of Ipituna, district of Valão do Barro, municipality of São Sebastião do Alto. Area B included the towns of Boa Esperança and Valão dos Milagres, district of Cambiasca, municipality of São Fidélis (Figure 1). The study areas met all the following criteria: (i) recently observed autochthonous cases of CD identified in this study, (ii) controlled environmental surveillance reporting cases of regular collection of triatomine bugs from houses, (iii) the presence of Program of Community Health or Family Health Strategy workers, and (iv) municipalities that had higher number of autochthonous cases of CD observed in the present study.

The study area is located $250 \mathrm{~km}$ from the state capital (Rio de Janeiro municipality) in a transition area between the Serrana and Northern regions at an altitude of approximately $200 \mathrm{~m}\left(21^{\circ} 45^{\prime} 18^{\prime \prime} \mathrm{S} 41^{\circ} 58^{\prime} 12^{\prime \prime} \mathrm{W}\right.$ [area A] and $21^{\circ} 43^{\prime} 23^{\prime \prime} \mathrm{S} 41^{\circ} 52^{\prime} 28^{\prime \prime} \mathrm{W}$ [area B]). The climate is tropical with 1000-1500 mm annual rainfall. The region has many valleys that are crossed by the Negro and Grande rivers; these rivers join Cambiasca to form Dois Rios river, one of the main tributaries of Paraiba do Sul river. The landscape is degraded with many pastures and secondary forest niches with fragments of Atlantic Forest in the tops of the hills. Most houses in the study area are small rural properties of agricultural families. Vegetables and dairy farming are the main economic activities of the region.

\section{Field study participants}

All houses in the region were visited by Family Health Strategy workers, and residents in $71.1 \%$ of them $(\mathrm{n}=$ 106 and 139 in areas A and B, respectively) filled out the questionnaire and donated a blood sample. A total of 404 peripheral blood samples were collected on filter paper (Klabin $\mathrm{n}^{\circ} 80$ ) via finger puncture, packed in individual plastic bags, and sent to the immunodiagnostic laboratory at INI, where the filters were eluted in distilled water and the serological reaction was carried out by performing IIF and ELISA. The age of participants ranged from 2 to 90 years old. Epidemiological information, including housing characteristics; the presence of pets; and the consumption of wild animals, sugarcane juice, and açaí palm juice, were recorded on the questionnaires. Participant knowledge about triatomine bugs was determined using a display case containing 2 adult specimens and 2 nymphs of $T$. vitticeps and T. infestans species.

\section{Small mammal trapping and sample collection}

Tomahawk (Tomahawk ${ }^{\circ}$ ) and Sherman $\left(\right.$ Sherman $\left.^{\circ}\right)$ live traps were placed for 4 consecutive nights in several sites around the houses in the study areas to capture small, wild, synanthropic mammals between July $12^{\text {th }}$ and $15^{\text {th }}$, 2010. Forty-five traps of each model baited with a mixture of peanut butter, banana, oat, and bacon were used per night, totaling 360 traps. The identification of mammals was made by morphological characteristics and karyriologic analyses as previously described [34]. In a field laboratory set up exclusively for this purpose, blood samples were collected via intracardiac puncture and processed as follows: (i) $0.6 \mathrm{~mL}$ of blood was cultured in two tubes containing Novy-Mc Neal-Nicoly medium (NNN) with a LIT overlay (hemoculture); and (ii) the remaining blood was 


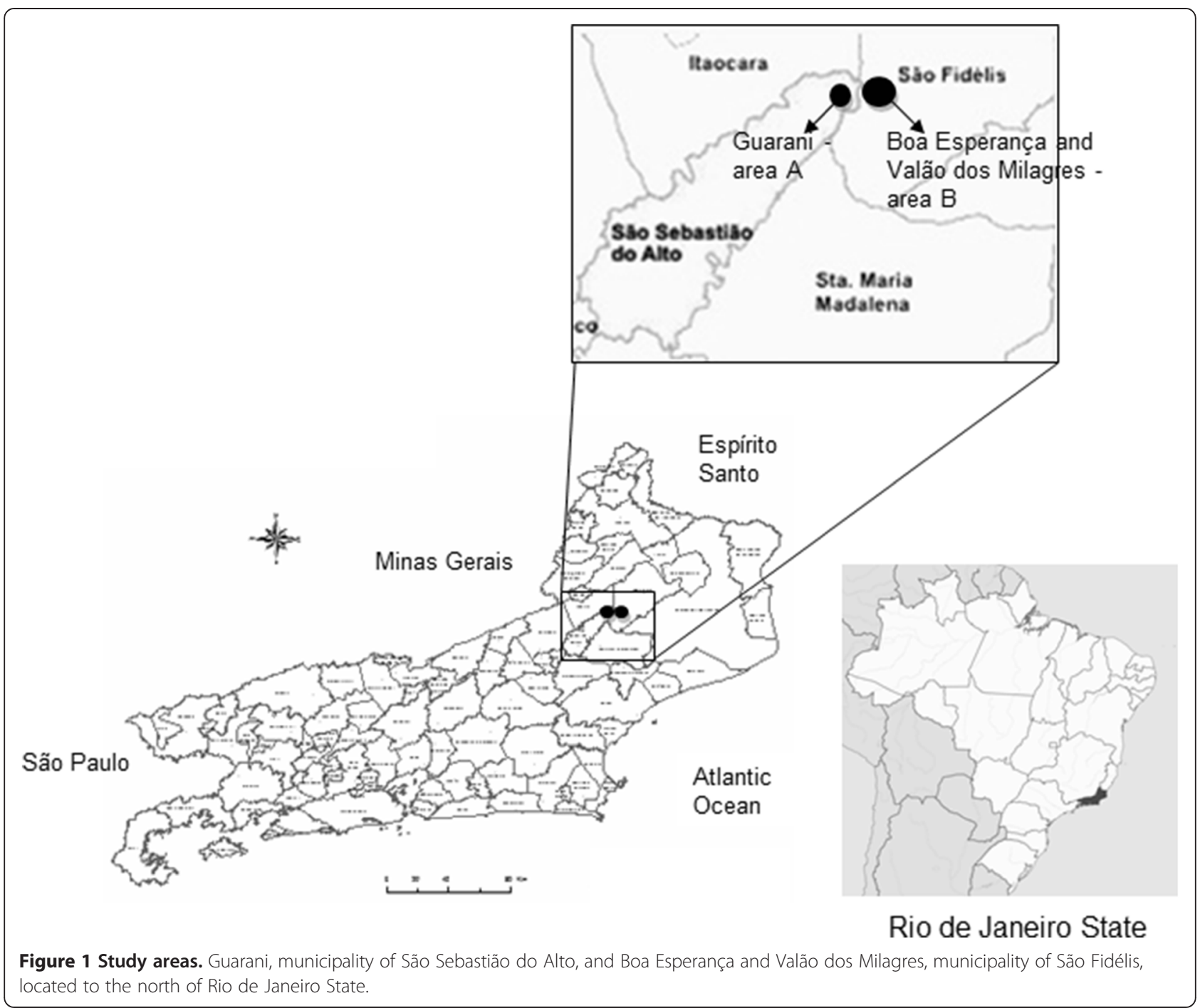

centrifuged and the serum was stored at $-20^{\circ} \mathrm{C}$ prior to serological analysis using IIF, as previously described [35]. The T. cruzi isolated obtained was characterized using mini-exon multiplex PCR, as described by Fernandes et al. [30].

\section{Triatomine bugs}

Between July 2010 and November 2012, triatomine bugs were manually collected with forceps from houses in the study areas and placed into individual plastic vials with a screw cap on which the location and collection date were written. Triatomine bugs collected in the same period in other localities of the municipalities where the field study was developed were also analyzed. Four different researchers captured the triatomines: two in the area A and two in the area B. However, around $30 \%$ of the triatomines were collected by the residents themselves and given to the researchers or community health workers. No dislodging agent was used to collect triatomines. Most of the captures were done during the day and flashlights were used whenever the sunlight was insufficient. The samples were sent to the Eco-epidemiology Laboratory of Chagas Disease at IOC/FIOCRUZ where light microscopy (400x) was used to identify tripanosomatids in the feces. The bugs that arrived alive in the laboratory were selected for miniexon multiplex PCR study of the intestines for T. cruzi infection, according to previously described methodology $[30,36]$. Beyond the proportion of natural infection by $T$. cruzi, others two entomological indicators (density index and crowding index) from the two study areas were calculated based on the number of triatomine bugs collected and houses visited by the study team, as recommended by WHO and discussed by Dias and Diotaiuti [37].

\section{Ethical considerations}

This study was approved by the Human Research Ethics Committee at INI/FIOCRUZ (license 016/2011). All patients and field study participants signed informed 
consents, indicating agreement to participate in the study. The study of wild animals was based on protocols that were approved by the FIOCRUZ Committees of Bioethics (license 0015-07), and wild animal captures were licensed by the Brazilian Institute of Environment and Renewable Natural Resources (IBAMA/CGFAU/LIC) (license 3665-1).

\section{Results}

\section{Case-series study}

From a total of 1963 patients, 69 (3.5\%) were native to RJ. The mechanism of transmission was considered to be congenital in 32 (46.4\% of the cases), blood transfusion in 10 (14.5\%), transmission outside RJ in 7 (10.1\%), and autochthonous in 15 patients $(21.7 \%)$. The patients from the first three subgroups were all born in urban areas. Most of the 15 patients classified as autochthonous vector transmission were natives from rural areas of the state, with 13 originating from municipalities in the northern areas of the RJ: São Fidélis $(n=5)$, São Sebastião do Alto $(n=2)$, Campos dos Goytacazes $(n=1)$, Santa Maria Madalena $(n=1)$, Conceição de Macabu $(\mathrm{n}=1)$, Bom Jesus do Itabapoana $(\mathrm{n}=1)$, Cardoso Moreira $(\mathrm{n}=1)$, and São Francisco de Itabapoana $(\mathrm{n}=1)$. One patient originated from Itaboraí (metropolitan region) and another from Resende (southern RJ region) (Figure 2). There was insufficient epidemiological information for 5 patients to define the form and site of transmission.

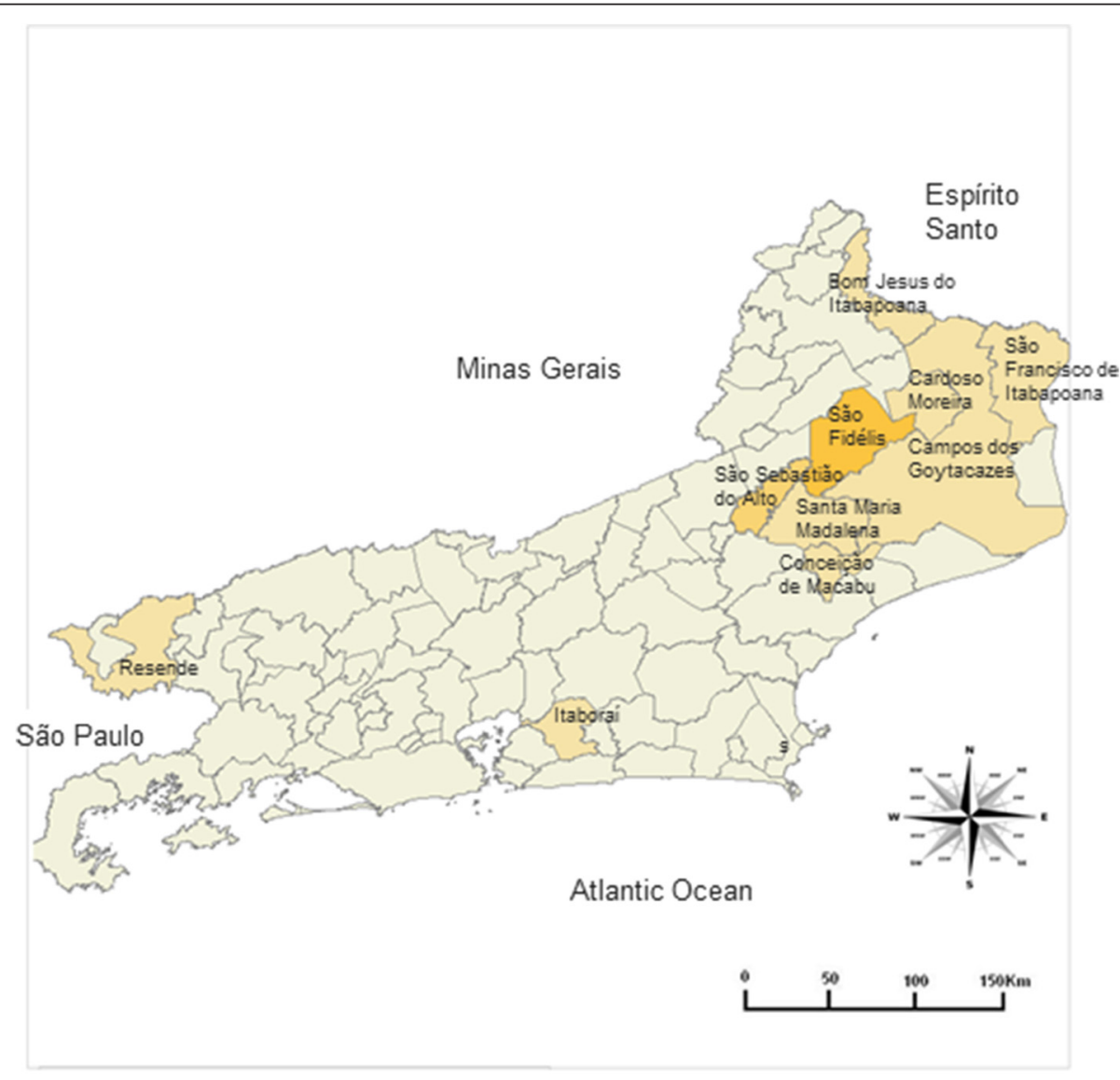

Legend

Municipalities

Cases

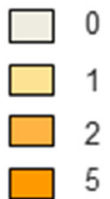

Figure 2 Distribution of 15 cases of native vectorial transmission of Chagas disease according to city of birth in Rio de Janeiro State. 
All following data refer to the patients considered to have acquired $\mathrm{CD}$ by autochthonous vectorial transmission. Most patients were male (12 male [80\%] and 3 female $[20 \%])$. All patients stated that they had resided in wattle and daub houses for the first decades of their life and 7 had seen triatomine bugs in their houses. All patients consumed bush meat (armadillo, opossum, cavy, and pacas) and sugarcane juice. Only 2 patients mentioned sporadic consumption of açaí palm juice.

From the 15 cases, 5 were considered to present the indeterminate form, 8 the cardiac form, 1 the digestive form and 1 the mixed cardiac and digestive form. From the 8 patients with the cardiac form, five presented the stage A, two the stage $B$ and one the stage $C$ of the cardiac form. The patient with the digestive form presented megaesophagus grade III and the one with the mixed form presented megaesophagus grade II (Table 1). Two young patients with the indeterminate form were treated with benznidazole. Of the 8 patients with $\mathrm{CD}$ cardiac form, 3 patients died before the start of the study: 1 due to sudden death, 1 due to refractory heart failure, and 1 due cervical cancer.

The 15 patients considered to have acquired CD by autochthonous vectorial transmission presented positive IIF and ELISA CD serological tests. Of these, 12 underwent indirect xenodiagnoses, with 1 positive result, and
11 underwent molecular studies. Four patients presented positive result in kDNA PCR and one patient presented a mixed infection with TcI and TcII genotypes in the mini-exon multiplex PCR and the DTUs were characterized as TcI and TcVI by performing RFLP analysis of the gene histone $\mathrm{H} 3$ and gp72 (Figure 3). Hemoculture for T. cruzi was negative in all samples.

\section{Field study}

In the field study, 245 rural properties in Northern region of RJ were studied, $84 \%$ of which had brick walls, $16 \%$ had wattle and daub walls, and $84 \%$ had tile roofs without ceilings. Knowledge of the vector was reported by $35 \%$ of residents. From the 404 blood samples collected from participants, 3 were found be serologically positive for $C D$ ( 1 adolescent and 2 adults), yielding a prevalence of $0.74 \%$. The 3 positive samples belonged to patients previously identified with $\mathrm{CD}$ and followed at the outpatient center of the INI/FIOCRUZ and who also resided in the study areas (see Table 1, cases 10, 13, and 14).

A total of 34 small wild mammals were captured including two marsupial species (Didelphis aurita and Philander frenatus) and four rodent species (Akodon cursor, Nectomys squamipes, Oligoryzomys nigripes and Rattus rattus). T. cruzi infection was found in 3 specimens (8.8\%); two by serological assay (D. aurita and $R$.

Table 1 Clinical data of patients Chagas disease (CD), from Rio de Janeiro with autochthonous vectorial transmission

\begin{tabular}{|c|c|c|c|c|c|c|c|c|c|c|c|}
\hline \multirow[t]{2}{*}{ Case } & \multicolumn{11}{|c|}{ Clinical and laboratory data } \\
\hline & Age & $\begin{array}{l}\text { Clinical } \\
\text { form }\end{array}$ & Follow-up & IIF & ELISA & ECG & ECO (EF\%) & Chest x-ray & Xeno & $\begin{array}{l}\text { kDNA } \\
\text { PCR }\end{array}$ & $\begin{array}{l}\text { m.exon } \\
\text { PCR }\end{array}$ \\
\hline 1 & 34 & CF & Death & $1 / 320$ & $1 / 640$ & $P R, P V C$ & Hypokinesia (45) & Normal & Neg & ND & ND \\
\hline 2 & 40 & CF & Death & $1 / 640$ & $1 / 1280$ & RBBB, LAHB, PVC, PAC & Hypokinesia $\uparrow$ LA (35) & Cardiomegaly & ND & ND & ND \\
\hline 3 & 48 & CF & Alive & $1 / 1280$ & $\mathrm{Rl} 4.8$ & RBBB, LAHB & Normal (75) & Normal & Neg & Neg & Neg \\
\hline 4 & 65 & CF & Death & $1 / 320$ & $1 / 640$ & RBBB, LAHB, PVC & Delayed relaxation (60) & Normal & ND & ND & ND \\
\hline 5 & 49 & IF & Alive & $1 / 320$ & $\mathrm{RI} 6.6$ & Normal & PDA (62) & Normal & Neg & Neg & Neg \\
\hline 6 & 46 & CF & Alive & $1 / 640$ & $\mathrm{RI} 4.0$ & RBBB, LAHB & Normal (66) & Normal & Neg & Neg & Neg \\
\hline 7 & 55 & CF & Alive & $1 / 640$ & RI 5.0 & LBBB, PVC & Normal (75) & Normal & Neg & Pos & Neg \\
\hline 8 & 57 & CF/DF & Alive & $1 / 640$ & $\mathrm{R} \mid 4.4$ & RBBB & Normal (76) & Megaesophagus & Pos & Neg & Neg \\
\hline 9 & 33 & CF & Alive & $1 / 320$ & RI 5.7 & Primary ST-T changes & Hypokinesia $\uparrow$ VE (53) & Normal & Neg & Neg & Neg \\
\hline 10 & 41 & IF & Alive & $1 / 40$ & RI 2.0 & Normal & Normal (68) & Normal & Neg & Neg & Neg \\
\hline 11 & 50 & DF & Lost to follow- up & $1 / 40$ & $\mathrm{RI} 1.5$ & Normal & - & Megaesophagus & ND & ND & ND \\
\hline 12 & 24 & IF & Alive & $1 / 80$ & $\mathrm{R} \mid 4.1$ & Normal & Normal (65) & Normal & Neg & Pos & Pos \\
\hline 13 & 15 & IF & Alive & $1 / 160$ & $\mathrm{RI} 6.2$ & Normal & Normal (67) & Normal & Neg & Pos & Neg \\
\hline 14 & 34 & IF & Alive & $1 / 160$ & $\mathrm{RI} 6.4$ & Normal & Normal (68) & Normal & Neg & Pos & Neg \\
\hline 15 & 68 & $\mathrm{CF}$ & Alive & $1 / 80$ & RI 1.1 & RBBB & Delayed relaxation (74) & Cardiomegaly & Neg & Neg & Neg \\
\hline
\end{tabular}

$\mathrm{CF}=$ cardiac form, $\mathrm{DF}=$ digestive form, $\mathrm{ECG}=$ electrocardiography; $\mathrm{ECO}=$ echocardiography, $\mathrm{EF}=$ ejection fraction, ELISA = enzyme-linked immunosorbent assay, $\mathrm{IF}=$ indeterminate form, IIF = indirect immunofluorescence, $\mathrm{kDNA}=$ kinetoplast DNA, LA = left atrium, LAHB = left anterior hemiblock, LBBB = left bundle branch block, $\mathrm{LV}=$ left ventricle, $\mathrm{m}$.exon $=$ mini-exon multiplex, $\mathrm{ND}=$ not determined; $\mathrm{PAC}=$ premature atrial complex, $\mathrm{PCR}=$ polymerase chain reaction, $\mathrm{PDA}=$ patent ductus arteriosus, $\mathrm{PVC}=$ premature ventricular complex, $\mathrm{PR}=$ pacemaker rhythm, $\mathrm{x}$-ray = radiograph, $\mathrm{RBBB}=$ right bundle branch block, $\mathrm{RI}=$ reactivity index.

The ages described are from the beginning of the patients' follow-up at our outpatient service. Except for cases 1, 2 and 4 who died before the start of this study, all clinical and laboratory data were reevaluated to check for serological and molecular diagnosis and the clinical form presentation. All patients presented negative hemoculture for $T$. cruzi. 


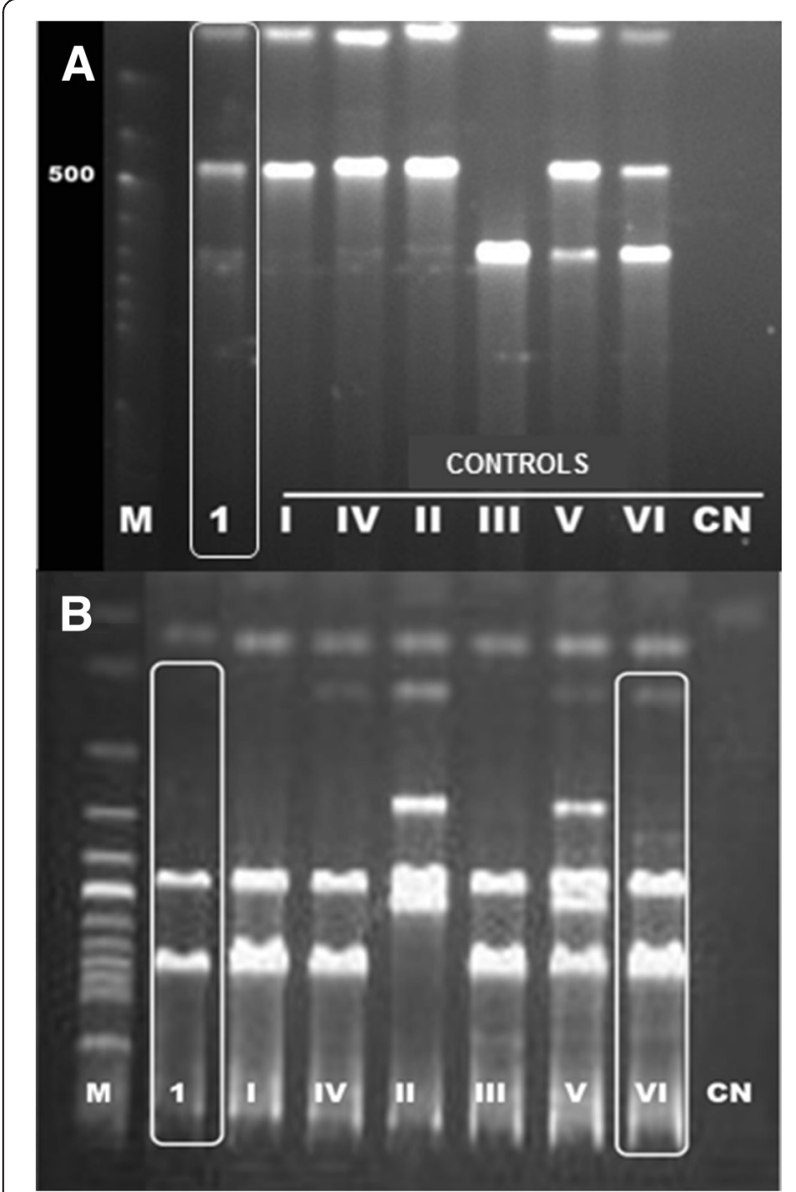

Figure 3 Agarose gel electrophoresis with the molecular characterization of mixed infection with genotypes DTUs $\mathrm{Tcl}+$ Tcll / TcV / TcVI T. cruzi by RFLP PCR. A. Profile fragments of the $P C R$ products $\mathrm{H} 3$ gene after digestion with restriction enzyme Alul; 1- patient (case 12), positive controls TCl-VI, CN-negative reaction control. B. Profile fragments of the PCR products of the gp72 gene after digestion with restriction enzyme Taql; 1 - patient (case 12), positive controls TCl-VI, CN-negative reaction control. M-molecular weight $100 \mathrm{bp}$.

rattus) and one by positive hemoculture (A. cursor). The positive hemoculture was characterized as TcI (Table 2) and deposited in the Trypanosoma from Sylvatic and Domestic Mammals and Vector Collection of Oswaldo Cruz Foundation (ColTryp 00356).

A total of 49 triatomine bugs of the species $T$. vitticeps were collected from inside houses (42 adults and 7 nymphs). In the two study areas, the study team collected 25 triatomine bugs in 20 (8.2\%) of the 245 homes visited while up to $35 \%$ of the residents who answered the questionnaires reported that they had already seen triatomine bugs inside their houses. The density index was 0.102 and the crowding index 1.25.Three out of 26 triatomine bugs (11.5\%) whose feces were analyzed under the light microscope showed tripanosomatids similar to T. cruzi. Other triatomine bugs could not be analyzed because they were very dry and without any intestinal contents. TcI genotype was identified in 8 out of $11(73 \%)$ triatomine bugs analyzed by mini-exon multiplex PCR (Table 3).

\section{Discussion}

In this paper, we were able to identify cases of autochthonous CD transmission within a population of patients born in RJ. Moreover, among patients with CD born in RJ followed at our institution, congenital transmission was the most common mode of CD transmission, while autochthonous transmission was the second most common mode and transfusion was the third most common mode of CD transmission. This is a clear contrast with the previous concept that transfusion would be the main mode of $\mathrm{CD}$ transmission in Brazilian urban areas $[38,39]$. In fact, a comprehensive study carried out in 1965 found only 3 cases of transfusional transmission in patients born in RJ [12]. Transfusional transmission in Brazil may have been overestimated, considering that a large proportion of donated blood in cities had been serologically screened, even without strict governmental control [38]. Together with the fact that congenital transmission is more common in other South American countries, such as Bolivia, Argentina, and Chile, new studies on the epidemiological nature of $C D$ in urban areas of Brazil are necessary [40-42]. Most of the patients with a history compatible with autochthonous vectorial transmission came from a common geographic rural area of RJ, comprising the serrana, north and northwest regions up to the state boundary with ES, where we found $T$. vitticeps specimens inside houses. The visits conducted by environmental surveillance agents in the present study revealed that triatomine bugs are regularly found in houses in at least 5 municipalities of the region (São Fidélis, São Sebastião do Alto, Santa Maria Madalena, Conceição de Macabu, and Trajano de Moraes). Other studies also described the presence of $T$. vitticeps specimens in houses in the same region [18-21,23]. Furthermore, other studies also described patients with CD born in the Northern region of RJ $[11,15]$.

The autochthonous CD transmission in the Northern region of RJ probably occurs by sporadic invasion of homes by $T$. vitticeps which are infected by $T$. cruzi due to a sylvatic cycle including sylvatic reservoirs living in areas surrounding the houses. This is similar to the CD epidemiological behavior reported in ES, which is usually associated with the presence of $T$. vitticeps in homes [24,43-45]. On the other hand, the prevalence of CD in ES and in the Northern region of RJ described by us is low, as $T$. vitticeps seldom colonizes houses and due to its low vector potential $[21,24,25,44]$. In fact, nymphs were captured in only $5 \%$ of the houses where triatomine bugs were found in this study, which demonstrates 
Table 2 Serology, hemoculture and PCR for Trypanosoma cruzi of small mammals captured to the north of RJ

\begin{tabular}{|c|c|c|c|c|c|}
\hline Species & Captured & Positive IIF & Positive hemoculture & Genotype mini-exon PCR & $\%$ positive \\
\hline Didelphis aurita & 3 & 1 & - & - & 33.3 \\
\hline Philander frenatus & 2 & - & - & - & - \\
\hline Akodon cursor & 24 & - & 1 & $\mathrm{Tcl}$ & 4.2 \\
\hline Nectomys squamipes & 1 & - & - & - & - \\
\hline Oligoryzomys nigripes & 2 & - & - & - & - \\
\hline Rattus rattus & 2 & 1 & - & - & 50 \\
\hline Total & 34 & 2 & 1 & & 8.8 \\
\hline
\end{tabular}

$\mathrm{IIF}=$ indirect immunofluorescence, $\mathrm{PCR}=$ polymerase chain reaction, $\mathrm{RJ}=$ Rio de Janeiro State.

that this species do not usually adapt to the domestic environment, unlike other wild vectors that have adapted to domestic environments, such as $P$. megistus, Triatoma sordida, and T. brasiliensis [46]. Despite the low entomological indicators, the triatomines collected in this study presented high level of natural infection by $T$. cruzi, as showed in others researches, which may contribute to the risk of CD transmission $[21,47]$. Home invasion by sylvatic vectors is a great challenge for epidemiological surveillance in several countries. Enzootic cycles of T. cruzi involved in the emergence of human cases of CD have been documented in other regions of Brazil, Latin America and in the USA $[2-7,48]$.

Many factors may influence the presence of autochthonous cases of CD in RJ, such as past and present occurrence of $T$. vitticeps, a species endemic in the Northern region of RJ; continuous deforestation with successive economic cycles in the region; the presence of rural inhabitants with permanent farming settlements; and a high number of dwellings of low socioeconomic status [19-21,49]. Additionally, vectors which usually invade but do not colonize homes are attracted to house lights and the absence of ceilings, window glass, and screens in many of the houses visited in the field study provides the best conditions for invasion [21,23]. The consume of wild animals may also contribute to the emergence of human cases of CD not only due to the risk of accidental infection from undercooked meat, but also due to the decrease in wild food sources for triatomine bugs [46,50-52]. Other factor that might contribute to the occurrence of autochthonous cases of CD in RJ would be the consumption of beverages, such as sugarcane juice and açaí palm juice [52,53]. However, this is unlikely as sugarcane juice consumption was related to outbreaks of acute $\mathrm{CD}$ due to the ingestion of

Table 3 Data from Triatoma vitticeps bugs collected indoors in 3 municipalities to the north of RJ

\begin{tabular}{|c|c|c|c|c|c|c|c|c|c|c|c|c|}
\hline \multirow[b]{2}{*}{ Location } & \multirow[b]{2}{*}{ District } & \multirow[b]{2}{*}{ Municipality } & \multicolumn{10}{|c|}{ Number of triatomine bugs } \\
\hline & & & Adults & Nymphs & Male & Female & Microscopy & Positive & $\%$ & PCR & Positive & $\%$ \\
\hline Guarani & Valão do Barro & $\begin{array}{l}\text { São Sebastião do } \\
\text { Alto }\end{array}$ & 8 & - & 3 & 5 & 5 & - & - & 4 & 3 & 75 \\
\hline Cabeceira & Valão do Barro & $\begin{array}{l}\text { São Sebastião do } \\
\text { Alto }\end{array}$ & 2 & - & - & 2 & 1 & - & - & 1 & - & - \\
\hline Centro & $\begin{array}{l}\text { São Sebastião do } \\
\text { Alto }\end{array}$ & $\begin{array}{l}\text { São Sebastião do } \\
\text { Alto }\end{array}$ & 6 & - & 2 & 4 & 3 & - & - & 2 & 2 & 100 \\
\hline Centro & Valão do Barro & $\begin{array}{l}\text { São Sebastião do } \\
\text { Alto }\end{array}$ & 4 & - & 1 & 3 & 1 & - & - & 1 & 1 & 100 \\
\hline $\begin{array}{l}\text { Valão dos } \\
\text { Milagres }\end{array}$ & Cambiasca & São Fidélis & 3 & - & 1 & 2 & 2 & 1 & 50 & - & - & - \\
\hline Boa Esperança & Cambiasca & São Fidélis & 13 & - & 2 & 6 & 4 & - & - & - & - & - \\
\hline São Tomé & Cambiasca & São Fidélis & 1 & - & - & 1 & - & - & - & - & - & - \\
\hline Grumarim & São Fidélis & São Fidélis & 1 & - & - & 1 & 1 & 1 & 100 & - & - & - \\
\hline Retiro Saudoso & Colônia & São Fidélis & 1 & 6 & - & 1 & 7 & 1 & 14.3 & - & - & - \\
\hline Colégio de Cima & Colônia & São Fidélis & - & 1 & - & - & - & - & - & - & - & - \\
\hline Triunfo & Triunfo & $\begin{array}{l}\text { Santa Maria } \\
\text { Madalena }\end{array}$ & 3 & - & 1 & 2 & 2 & - & - & 3 & 2 & 66 \\
\hline Total & & & 42 & 7 & 11 & 31 & 26 & 3 & 11.5 & 11 & 8 & 73 \\
\hline
\end{tabular}

$\mathrm{PCR}=$ polymerase chain reaction, $\mathrm{RJ}=$ Rio de Janeiro State. 
large numbers of parasites when triatomine bugs were crushed together with the plant, which was not observed in RJ $[53,54]$. Moreover, there is no previous description of $\mathrm{CD}$ transmission by consumption of the E. edulis palm juice, which is the açaí palm commonly found in the Atlantic Forest. Furthermore, only two patients reported the sporadic consumption of the E. edulis palm juice and this mode of CD transmission would be associated with acute $C D$ cases occurring within families which are not described in RJ [52]. Another possible mechanism of oral transmission is the accidental contamination of food with feces of infected triatomine bugs or by $T$. cruzi in the anal gland contents of infected opossums $[40,55,56]$. The present study documents the natural infection of triatomine bugs and wild animals by T. cruzi in areas surrounding the houses in the field study sites, including 1 opossum $(D$. aurita), which supports this hypothesis. Therefore, the vector contaminative transmission is the most probable among the 15 patients but we cannot completely rule out other possibilities, such as the consumption of food contaminated with triatomine bugs feces or anal gland contents of opossums infected with T. cruzi.

Most of the T. vitticeps studied were collected during months when the temperature and relative humidity are usually the highest in Brazil, which coincides with the period when there is the greatest dispersion of triatomine bugs [21,57]. Additionally, more female bugs were captured, similar to the findings in other studies $[21,47]$. It was confirmed that the majority of triatomine bugs captured in houses did not have any intestinal contents, indicating the difficulty to find food sources in the wild, which could influence the dispersion intensity of the vectors [21].

TcI was found in all 3 participants of the protozoan life cycle (vector, animal reservoir, and human host). Moreover, in one human host was identified mixed infection by TcI and TcVI. Although the visceral forms (cardiac and digestive) of the disease predominated in autochthonous patients described in this study, it was not possible to correlate the severity of the presentation of the disease with the T. cruzi genotype as the specific genotype was identified in only one case. The low sensitivity of PCR in this study can be explained by the fact that all studied patients presented chronic CD and most of them moved away from the endemic areas decades ago. These conditions determine a low and irregular parasitemia and PCR performed in patients under such conditions usually do not present high sensitivity [58]. The low and irregular parisitemia may have also contributed to the discordance between indirect xenodiagnoses and PCR results as the samples used to run those exams were collected in different days. We consider that most of the cases described in this study were caused by TcI as this was the genotype identified from vectors and animal reservoirs. TcI is found in humans in the Amazon in Brazil and was also found in humans in the Northeast region of Brazil, and in Argentina and Bolivia [59-61]. The high prevalence of visceral forms found by us contradicts the idea that $\mathrm{CD}$ morbidity is lower in cases from RJ inhabitants [48]. Moreover, Chagas heart disease have already been documented in the Amazon, a region where TcI infections predominate [30,62,63]. TcVI was first identified in Brazil in vectors captured in Rio Grande do Sul State [33,59] and, thereafter, in patients affected by the outbreak of acute CD in Santa Catarina State in 2005 and in Minas Gerais State [64,65]. Study genotyping of $T$. cruzi in sylvatic cycles previously conducted in RJ had already revealed the complexity of genotypes in the state, with findings of TcI and TCII and mixed infection by mini-exon gene PCR [66]. Given the unprecedented findings regarding molecular epidemiology in RJ, documented in the present study, and the still poorly understood parasite-host interactions regarding the various lineages of T. cruzi, further studies are required to better clarify these correlations and their implications in the morbidity of $\mathrm{CD}$ not only in RJ but also in other regions of Brazil and Latin America.

With regard to the 2 autochthonous CD cases that did not originate from north of the state, we consider that the case from Resende (south of the state) was related to vectorial transmission by $T$. infestans and the mode of transmission of the case from Itaboraí (a metropolitan region) was similar to the other autochthonous cases described in this study. Several evidences indicate that the vector involved in the transmission to the patient from Resende was $T$. infestans. The patient was born in Engenheiro Passos, a rural district of Resende, in 1944 and T. infestans infected by $T$. cruzi was documented in the same area during the 1940s and 1950s [17,19]. T. infestans in this area probably originated from the municipality of Queluz, São Paulo State, which borders Engenheiro Passos [17,67]. The patient lived in a wattle and daub house and knew about triatomine bugs because they were spotted daily on the walls inside the house. Furthermore, in a study of 1952 carried out in South of RJ no other vector apart from $T$. infestans was documented and we did not find any publication referring to the presence of other triatomine bugs invading houses in Resende [17]. Regarding the case from Itaboraí, both oral and vectorial transmission are possible to have occurred as the patient frequently ate opossums hunted in the region and consumed sugarcane juice since childhood and he always lived in rural areas in the district of Sambaetiba in poor houses without ceilings or window screens. Moreover, T. vitticeps was found in rural areas of municipalities near Itaboraí $[20,66]$. However, in a separate study carried out in Sambaetiba, no relative had serological positive results for $\mathrm{CD}$, and no vector was found in the houses or their annexes, even though the current 
address of the family is in the same district where the patient was born and lived the first years of life.

\section{Conclusions}

The eventual vectorial transmission of $\mathrm{CD}$ occurs in $\mathrm{RJ}$ since many years ago, probably due to wild cycles of $T$. cruzi and sylvatic vectors, such as $T$. vitticeps. Therefore, even among patients born in RJ, CD should always be included in the diagnostic work out of cardiomyopathy. On the basis of the findings of this study, we recommend that the health authorities should evaluate if RJ should be included in the original endemic area of CD and that control and educational measures should be put into place in the risk areas.

\begin{abstract}
Abbreviations
CD: Chagas disease; DTUs: Discrete typing units; ECG: Electrocardiography; ECO: Echocardiography; EDTA: Ethylenediaminetetraacetic acid; ELISA: Enzyme-linked immunosorbent assay; ES: Espírito Santo State; FIOCRUZ: Oswaldo Cruz Foundation; IIF: Indirect immunofluorescence; INI: Instituto Nacional de Infectologia Evandro Chagas; IOC: Instituto Oswaldo Cruz; KDNA: Kinetoplast deoxyribonucleic acid; LIT: Liver infusion tryptose medium; NNN: Novy-Mc Neal-Nicoly medium; PCR: Polymerase chain reaction; RFLP: Restriction fragment length polymorphism; RJ: Rio de Janeiro State; WHO: World Health Organization.
\end{abstract}

\section{Competing interests}

The authors declare that they have no competing interests.

\section{Authors' contributions}

LHCS conceived the study, carried out the design, coordination, project/ protocol development review, data analysis and wrote the manuscript. RMS analyzed the data, proofread and wrote the manuscript. IG performed the serological analysis and proofread the manuscript. LDeC performed the kDNA PCR analysis and proofread the manuscript. VSL performed the hemocultures, genotyping in human cases and proofread the manuscript. ALRR performed the hemocultures, PCR in animal reservoirs and proofread the manuscript. SCCX performed the serological analysis in animal reservoirs. LCS performed the indirect xenodiagnoses. FAF performed the capture of wild animals, sample preparation and data analysis. OS performed the collection of triatomine bugs, direct search of $T$. cruzi, data analysis and proofread the manuscript. MML conceived the study and proofread the manuscript. FACC conceived the study, wrote manuscript. MNB conceived the study, data analysis and proofread the manuscript. All authors read and approved the final manuscript.

\section{Acknowledgements}

We thank the community health workers and Environmental Surveillance of the municipalities of São Fidélis and São Sebastião do Alto for inestimable help during field study. We thank Dr. Patrícia Azambuja of the Biochemistry and Physiology of Insects Laboratory, IOC/FIOCRUZ, for helping with the PCR performed in triatomine bugs.

\footnotetext{
Author details

'Laboratório de Pesquisa Clínica em Doença de Chagas, Instituto Nacional de Infectologia Evandro Chagas, Fundação Oswaldo Cruz, Rio de Janeiro, RJ Brazil. ${ }^{2}$ Laboratório de Imunodiagnóstico, Instituto Nacional de Infectologia Evandro Chagas, Fundação Oswaldo Cruz, Rio de Janeiro, Brazil. ${ }^{3}$ Laboratório de Farmacocinética, Instituto Nacional de Infectologia Evandro Chagas, Fundação Oswaldo Cruz, Rio de Janeiro, Brazil. " Laboratório de Biologia de Tripanossomatídeos, Instituto Oswaldo Cruz, Fundação Oswaldo Cruz, Rio de Janeiro, Brazil. ${ }^{5}$ Laboratório de Doenças Parasitárias, Instituto Oswaldo Cruz, Fundação Oswaldo Cruz, Rio de Janeiro, Brazil. '́Laboratório de Ecoepidemiologia da Doença de Chagas, Instituto Oswaldo Cruz, Fundação Oswaldo Cruz, Rio de Janeiro, Brazil. 'Laboratório de Sistemática e Bioquímica, Instituto Oswaldo Cruz, Fundação Oswaldo Cruz, Rio de Janeiro, Brazil. ${ }^{8}$ Laboratório de Biologia e Parasitologia de Mamíferos Silvestres
}

Reservatórios, Instituto Oswaldo Cruz, Fundação Oswaldo Cruz, Rio de Janeiro, Brazil.

Received: 16 August 2014 Accepted: 19 December 2014 Published online: 08 January 2015

\section{References}

1. Moncayo A, Silveira AC. Current epidemiological trends for Chagas disease in Latin America and future challenges in epidemiology, surveillance and health policy. Mem Inst Oswaldo Cruz. 2009;104(Suppl I):17-30.

2. Guhl F, Pinto N, Aguilera G. Sylvatic triatominae: a new challenge in vector control transmission. Mem Inst Oswaldo Cruz. 2009;104(Suppl I):71-5.

3. Borges-Pereira J, Sarquis O, Zauza PL, Brito C, Lima MM. Epidemiologia da doença de Chagas em quatro localidades rurais de Jaguaruana, Estado do Ceará. Soroprevalência da infecção, parasitemia e aspectos clínicos. Rev Soc Bras Med Trop. 2008;41(4):345-51.

4. Bern C, Kjos S, Yabsley MJ, Montgomery SP. Trypanosoma cruzi and Chagas' Disease in the United States. Clin Microbiol Rev. 2011;24(4):655-81.

5. Abad-Franch F, Diotaiuti L, Gurgel-Gonçalves R, Gurtler RE. Certifying the interruption of Chagas disease transmission by native vectors: cui bono? Mem Inst Oswaldo Cruz. 2013;108(2):251-4.

6. Abad-Franch F, Diotaiuti L, Gurgel-Goncalves R, Gurtler RE. On bugs and bias: improving Chagas disease control assessment. Mem Inst Oswaldo Cruz. 2014;109(1):125-30.

7. Vinhaes MC, Oliveira SV, Reis PO, Sousa ACL, Silva RA, Obara MT, et al. Assessing the vulnerability of Brazilian municipalities to the vectorial transmission of Trypanosoma cruzi using multi-criteria decision analysis. Acta Trop. 2014;137:105-10.

8. Silveira AC, Feitosa VR, Borges R. Distribuição de triatomíneos capturados no ambiente domiciliar no período de 1975/83, Brasil. Rev Bras Malariol D Trop. 1984;36:15-312.

9. Silveira AC, Dias JCP. O controle da transmissão vetorial. Rev Soc Bras Med Trop. 2011;44(Suppl I):52-63.

10. Ministério da Saúde, Secretaria de Vigilância em Saúde. [Brazilian Consensus on Chagas disease]. Rev Soc Bras Med Trop. 2005;38 Suppl 3:7-29.

11. Benchimol AB, Schlesinger $P$, Cotrim MR. A cardiopatia Chagásica crônica observada na cidade do Rio de Janeiro: estudo de 32 casos. Med Cirurg Farm. 1954;213:5-30

12. Coura JR. Contribuição ao estudo da doença de Chagas no estado da Guanabara. Rev Bras Malariol D Trop. 1966;18:9-98.

13. Coura JR, Anunziato N, Willcox HPF. Morbidade da doença de Chagas. I - Estudo de casos procedentes de vários estados do Brasil, observados no Rio de Janeiro. Mem Inst Oswaldo Cruz. 1983;78(3):363-72.

14. Brito F. O deslocamento da população brasileira para as metrópoles. Estud av. 2006;20(57):221-36.

15. Coura JR, Silva CET, Vieira W, Figueiredo N. Um foco de doença de Chagas transmitida pelo Triatoma infestans na Baixada Fluminense, município de Caxias, estado do Rio de Janeiro, Brasil. Rev Soc Bras Med Trop. 1971;5(3):123-9.

16. Guimarães FN, Jansen G. Um foco potencial de Tripanosomíase Americana na cidade do Rio de Janeiro (Distrito Federal). Mem Inst Oswaldo Cruz. 1943;39(3):405-17.

17. Bustamante FM, Gusmão JB. Sobre um foco de Triatoma infestans nos municípios de Resende e Itaverá, estado do Rio de Janeiro. Rev Bras Malariol D Trop. 1953;5:23-8.

18. Neiva A, Pinto C. Dos reduvídeos hematófagos encontrados no Distrito Federal e Estado do Rio de Janeiro com descrição de uma espécie nova. Bras Med. 1923;37:45-7.

19. Lent H. Transmissores da moléstia de Chagas no Estado do Rio de Janeiro. Rev Flum Med. 1942;6:7-19.

20. Ferreira E, Souza OS, Fonseca-Filho M, Rocha I. Nota sobre a distribuição geográfica do Triatoma vitticeps Stal, 1859 (Hemiptera, Reduvidae) no estado do Rio de Janeiro, Brasil. Rev Bras Malariol D Trop. 1986;38:11-4.

21. Gonçalves TCM, Oliveira E, Dias LS, Almeida MD, Nogueira WO, Pires FDA. An Investigation on the Ecology of Triatoma vitticeps (Stal, 1859) and its Possible Role in the Transmission of Trypanosoma cruzi, in the Locality of Triunfo, Santa Maria Madalena Municipal District, State of Rio de Janeiro, Brazil. Mem Inst Oswaldo Cruz. 1998;93(6):711-7.

22. Lorosa ES, Valente MVM, Cunha V, Lent H, Juberg J. Foco da doença de Chagas em Arcádia, Estado do Rio de Janeiro, Brasil. Mem Inst Oswaldo Cruz. 2003;98(7):885-7. 
23. Lorosa ES, Santos CM, Juberg J. Foco da doença de Chagas em São Fidélis, no Estado do Rio de Janeiro. Rev Soc Bras Med Trop. 2008;41(4):419-20.

24. Dias JCP, Feitosa VR, Ferraz-Filho NA, Rodrigues VLC, Alencar AS, Sessa PA. Fonte alimentar e potencial vetorial de Triatoma vitticeps (Stal, 1859) com relação à doença de Chagas humana no estado do Espírito Santo, Brasil (Hemiptera, Reduviidae). Mem Inst Oswaldo Cruz. 1989;84(supl. IV):165-73.

25. Santos $C B$, Ferreira AL, Leite GR, Ferreira GEM, Rodrigues AAF, Falqueto A. Peridomiciliary colonies of Triatoma vitticeps (Stal, 1859) (Hemiptera, Reduviidae, Triatominae) infected with Trypanosoma cruzi in rural areas of the state of Espírito Santo, Brazil. Mem Inst Oswaldo Cruz. 2005;100(5):471-3.

26. Teicholz LE, Kreulen T. Problems in echocardiographic volume determinations: echocardiographic correlations in the presence or absence of asynergy. Am J Cardiol. 1976;37(1):7-11.

27. Lisboa CV, Mangia RH, Luz SL, Kluczkovski Jr A, Ferreira LF, Ribeiro CT, et al. Stable infection of primates with Trypanosoma cruzi I and II. Parasitology. 2006;133:603-11.

28. Avila HA, Sigman DS, Cohen LM, Millikan RC, Simpson L. Polymerase chain reaction amplification of Trypanosoma cruzi kinetoplast minicircle DNA isolated from whole blood lysates: diagnostic of chronic Chagas' Disease. Mol Biochem Parasitol. 1991;48(2):211-21.

29. Brito C, Cardoso MA, Ravel C, Santoro A, Borges-Pereira J, Coura JR, et al. Trypanosoma cruzi: parasite detection and strain discrimination in chronic chagasic patients from northeastern Brazil using PCR amplification of kinetoplast DNA and nonradioactive hybridization. Exp Parasitol. 1995;81(4):462-71.

30. Fernandes O, Santos SS, Cupolillo E, Mendonça B, Derre R, Junqueira AC, et al. A mini-exon multiplex polymerase chain reaction to distinguish the major groups of Trypanosoma cruzi and T. rangeli in the Brazilian Amazon. Trans R Soc Trop Med Hyg. 2001;95(1):97-9.

31. Westenberger SJ, Barnabé C, Campbell DA, Sturm NR. Two hybritization events define the population structure of Trypanosoma cruzi. Genectis. 2005;171(2):527-43.

32. Rozas M, De Doncker S, Adaui V, Coronado X, Barnabé C, Tibyarenc M, et al. Multilocus polymerase chain reaction restriction fragment-length polymorphism genotyping of Trypanosoma cruzi (Chagas disease). J Infect Dis. 2007;195(9):1381-8.

33. Zingales B, Andrade SG, Briones MRS, Campbell DA, Chiari E, Fernandes O, et al. A new consensus for Trypanosoma cruzi intraspecific nomenclature: second revision meeting recommends Tcl to TcVI. Mem Inst Oswaldo Cruz. 2009;104(7):1051-4.

34. Bonvicino CR, Lemos B, Weksler M. Small mammals of Chapada dos Veadeiros National Park (Cerrado of Central Brazil) ecologic, karyologic, and taxonomic considerations. Braz J Biol. 2005;65(3):395-406.

35. Roque ALR, Xavier SCC, Gerhardt M, Silva MFO, Lima VS, D'Andrea PS, et al. Trypanosoma cruzi among wild and domestic mammals in different areas of the Abaetetuba municipality (Pará State, Brazil), an endemic Chagas disease transmission area. Vet Parasitol. 2013;193(1-3):71-7.

36. Silva MA, Nai GA, Rosa JA. Caracterização biológica e molecular de quatro cepas de Trypanosoma cruzi isoladas de pacientes na fase crônica, forma cardíaca da doença de Chagas. Rev Patol Trop. 2006;35(3):213-26.

37. Dias JCP, Diotaiuti LG. IWHO/TDR Technical report $n^{\circ} 811$ : small correction, proposal. Rev Soc Bras Med Trop. 1998;31(6):582-3.

38. Schmunis GA. Prevention of transfusional Trypanosoma cruzi infection in Latin America. Mem Inst Oswaldo Cruz. 1999;94(Suppl I):93-101.

39. Coura JR, Viñas PA. Chagas disease a new worldwide challenge. Nature. 2010;465(7301):S6-7.

40. Azogue E, La Fuent C, Darras C. Congenital Chagas disease in Bolivia: epidemiological aspects and pathological findings. Trans R Soc Trop Med Hyg. 1985;79(2):176-80

41. Negrette OS, Mora MC, Basombrío MA. High prevalence of congenital Trypanosoma cruzi infection and family clustering in Salta, Argentina. Pediatrics. 2005;115:e668-72.

42. Apt W, Zulantay I, Arnello M, Oddó D, González S, Rodríguez J, et al. Congenital infection by Trypanosoma cruzi in an endemic area of Chile: a multidisciplinary study. Trans R Soc Trop Med Hyg. 2013;107(2):98-104.

43. Santos UM, Murad V, Chapadeiro E, Lima FEP. Doença de Chagas no estado do Espírito Santo. IV- Primeiro caso diagnosticado no município de Rio Novo do Sul. Rev Soc Bras Med Trop. 1969;3(1):52-3.

44. Barros GC, Mayrink W, Salgado AA, Barros RCG, Sessa PA. Contribuição para o conhecimento da doença de Chagas autóctone no estado do Espírito Santo. Rev Inst Med Trop Sao Paulo. 1975;17(6):319-29.
45. Sessa PA, Pimentel RR, Ferreira AL, Falqueto A. Soroprevalência da doença de Chagas em crianças em idade escolar do Estado do Espírito Santo, Brasil, 1999-2000. Cad Saude Publica. 2002;18(6):1765-9.

46. Forattini OP. Biogeografia, origem e distribuição da domiciliação de triatomíneos no Brasil. Rev Saude Publica. 1980;14:265-99.

47. Santos CB, Leite GR, Ferreira GEM, Ferreira AL. Infecção natural de Triatoma vitticeps (Stal, 1859) por flagelados morfologicamente semelhantes a Trypanosoma cruzi (Chagas, 1909) no Estado do Espírito Santo. Rev Soc Bras Med Trop. 2006:39(1):89-91.

48. Coura JR, Borges-Pereira J. Chagas disease. What is known and what should be improved: a systemic review. Rev Soc Bras Med Trop. 2012;45(3):286-96.

49. Alentejano PRR. A evolução do espaço agrário fluminense. GEOgraphia. 2005;13:49-70

50. Dias JCP, Amato-Neto V. Prevenção referente às modalidades alternativas de transmissão do Trypanosoma cruzi no Brasil. Rev Soc Bras Med Trop. 2011;44(supl. II):67-72.

51. Coura JR, Barrett TV, Naranjo MA. Ataque de populações humanas por triatomíneos silvestres no Amazonas: uma nova forma de transmissão da infecção chagásica? Rev Soc Bras Med Trop. 1994;27(4):251-3.

52. Valente SAS, Valente VC, Faiha-Neto H. Considerations on the epidemiology and transmission of Chagas disease in Brazilian Amazon. Mem Inst Oswaldo Cruz. 1999;94(Suppl I):395-8.

53. Pereira KS, Schmidt FL, Guaraldo AMA, Franco RMB, Dias VL, Passos LAC. Chagas disease as a foodborne illness. J Food Prot. 2009;72(2):441-6.

54. Shikanai-Yasuda MA, Marcondes CB, Guedes LA, Siqueira GS, Barone AA, Dias JCP, et al. Possible oral transmission of acute Chagas' disease in Brazil. Rev Inst Med Trop Sao Paulo. 1991;33(5):351-7.

55. Deane MP, Lenzi HL, Jansen A. Trypanosoma cruzi: vertebrate and invertebrate cycles in the same mammal host, the opossum Didelphis marsupialis. Mem Inst Oswaldo Cruz. 1984;79(4):513-5.

56. Silva NN, Clausell DT, Núbilos H, Mello AL, Ossanai J, Rapone T, et al. Surto epidêmico de Doença de Chagas com provável contaminação oral. Rev Inst Med Trop Sao Paulo. 1968;10(5):265-76.

57. Souza RCM, Diotaiuti L, Lorenzo MG, Gorla DE. Analysis of the geographical distribution of Triatoma vitticeps (Stal, 1859) based on data species occurrence in Minas Gerais, Brazil. Infect Genet Evol. 2010;10(6):720-6.

58. Schijman AG, Bisio M, Orellana L, Sued M, Duffy T, Jaramillo AMM, et al. International study to evaluate PCR methods for detection of Trypanosoma cruzi DNA in blood samples from Chagas disease patients. PLoS Neglet Trop Dis. 2011:5(1):e931.

59. Zingales B, Miles MA, Campbell DA, Tibayrenc M, Macedo AM, Teixeira MMG, et al. The revised Trypanosoma cruzi subspecific nomenclature: rationale, epidemiological relevance and research applications. Infect Genet Evol. 2012;12(2):240-53.

60. da Câmara AC, Lages-Silva E, Sampaio GH, D’Ávila DA, Chiari E, da Cunha Galvão LM. Homogeneity of Trypanosoma cruzi I, II, and III populations and the overlap of wild and domestic transmission cycles by Triatoma brasiliensis in northeastern Brazil. Parasitol Res. 2013;112(4):1543-50.

61. Cura Cl, Mejía-Jaramillo AM, Duffy T, Burgos JM, Rodriguero M, Cardinal MV, et al. Trypanosoma cruzi I genotypes in different geographical regions and transmission cycles based on a microsatellite motif of the intergenic spacer of spliced leader genes. Int J Parasitol. 2010;40(14):1599-607.

62. Albajar PV, Laredo SV, Terrazas MB, Coura JR. Miocardiopatia dilatada em pacientes com infecção chagásica crônica. Relato de dois casos fatais autóctones no Rio Negro, Estado do Amazonas. Rev Soc Bras Med Trop. 2003;36(3):401-7.

63. Xavier SS, Sousa AS, Albajar-Viñas P, Junqueira ACV, Bóia MN, Coura JR Cardiopatia chagásica crônica no Rio Negro, Estado do Amazonas. Relato de três novos casos autóctones, comprovados por exames sorológicos, clínicos, radiográficos do tórax, eletro e ecocardiográficos. Rev Soc Bras Med Trop. 2006;39(2):211-6.

64. Andrade SG, Campos RF, Steindel M, Guerreiro ML, Magalhães JB, Almeida MC, et al. Biological, biochemical and molecular features of Trypanosoma cruzi strains isolated from patients infected through oral transmission during a 2005 outbreak in the state of Santa Catarina, Brazil: its correspondence with the new T. cruzi Taxonomy Consensus (2009). Mem Inst Oswaldo Cruz. 2011;106(8):948-56.

65. Oliveira MT. Genotipagem de amostras de Trypanosoma cruzi isoladas de pacientes chagásicos de dois municípios da região do Vale do Jequitinhonha, MG, Brasil. MSc dissertation, Universidade Federal de Ouro Preto, MG 2012, 110pp 
66. Fernandes $\mathrm{O}$, Mangia RH, Lisboa CV, Pinho AP, Morel CM, Zingales B, et al. The complexity of the sylvatic cycle of Trypanosoma cruzi in Rio de Janeiro state (Brazil) revealed by non-transcribed spacer of the mini-exon gene. Parasitology. 1999;118:161-6.

67. Silva EOR, Rodrigues VLCC, Silva RA, Wanderley DMV. Programa de Controle da Doença de Chagas no Estado de São Paulo, Brasil: o controle e a vigilância da transmissão vetorial. Rev Soc Bras Med Trop. 2011;44(Suppl II):74-84.

Submit your next manuscript to BioMed Central and take full advantage of:

- Convenient online submission

- Thorough peer review

- No space constraints or color figure charges

- Immediate publication on acceptance

- Inclusion in PubMed, CAS, Scopus and Google Scholar

- Research which is freely available for redistribution 